\title{
ROPE PROCEDURES FOR EXTRACTION AND INSERTION OF PERSONS USED BY HELICOPTER EMERGENCY MEDICAL SERVICE
}

\author{
Peter Kal'avský ${ }^{1}$, Róbert Rozenberg ${ }^{1}$, Pavol Petríček ${ }^{1}$, \\ Vladimír Socha ${ }^{2}$, Luboš Socha ${ }^{1}$ \\ ${ }^{1}$ Faculty of Aeronautics \\ Technical University of Kosice \\ Rampova 7, 04121 Kosice, Slovakia
}

peter.kalavsky@tuke.sk,robert.rozenberg@tuke.sk, palo.petricek@gmail.com, lubos.socha@tuke.sk

\author{
${ }^{2}$ Department of Air Transport \\ Czech Technical University in Prague \\ Horska 3, 12803 Prague 2, Czech Republic \\ vladimir.socha@fbmi.cvut.cz
}

Keywords: helicopter emergency medical service HEMS, rope, extraction, insertion, hoist, rappelling, human external cargo HEC

\begin{abstract}
The article deals with the issue of alternative ways of extraction and insertion of persons by helicopters using rope and non-rope procedures. The article provides a current general overview of rope and non-rope procedures for insertion of persons in places where a helicopter cannot touch down, as well as an overview of techniques used for extraction/transport of persons from places not permitting helicopter touchdown. The article lists advantages and disadvantages of individual methods and their applicability in the helicopter emergency medical service. The main contribution of the article is the comparison of time indicators when inserting and transporting persons by helicopters with the use of rope procedures during typical model situations. For the purposes of comparing rope procedures have been created three typical model situations for inserting two persons from a hovering helicopter and two typical model situations for extracting four persons and their transportation on board. During creating these model situations, we have taken into consideration the most frequently used rope procedures within HEMS in civil, military and police sectors of the Slovak Republic. Total insertion/extraction time was considered the basic piece of data for the comparison. Time data were obtained from flight tests, actual training, technical documentation data and on the basis of the expert estimate. Rope procedures were compared among each other and among three types of helicopters most used for these purposes in the Slovak Republic: Mi-17 LPZS, Bell-429 and AGUSTA A109K2. Processed conclusions from the comparison of each model situation within the considered alternative rope ways of extraction and insertion of persons by helicopters and the conclusions drawn from the performance comparison of HEMS helicopters in the Slovak Republic within these model situations are a significant contribution to the determination of procedures in the framework of rescue missions.
\end{abstract}

\section{INTRODUCTION}

Nowadays, the use of helicopters to provide assistance to persons in emergency is a frequently used method when searching for persons in danger, providing urgent medical assistance and evacuating persons from areas at risk. The benefits of such rescue operation are widely known, the most 
important ones being the time aspect and economical transport of injured persons. There are two ways of deploying helicopters for rescue operations:

- landing in the vicinity of the accident, which is conditioned by a suitable touchdown area,

- alternative ways of inserting the rescue team and evacuating persons from the places not permitting the helicopter touchdown due to the absence of a suitable touchdown area.

Due to the mountainous terrain of the Slovak Republic, which does not permit the helicopter touchdown on the approx. $50 \%$ of the country's territory, there is a need for the alternative ways of helicopter insertion and transport of persons using the helicopter (without its landing), these being essential for carrying out the tasks of search and rescue. The main purpose of the work is to make specific recommendations for choosing how to extraction or insertion of people by helicopters in terms of the number of these persons with regard to the time indicator.

\section{ROPE AND NON-ROPE PROCEDURES USED IN HEMS [1, 2, 4, 6$]$}

\subsection{Non-rope procedures for helicopter insertion of persons in places not permitting helicopter touchdown}

2.1.1 Helicopter disembarkation when the landing is not completed (the helicopter is hovering and the landing gear or its part is in contact with a natural or artificial object or surface, the so-called insertion when helicopter is leaning). It is the most frequently used procedure when the standard helicopter touchdown is not possible. From both time and safety point of view, it is almost comparable with the standard helicopter touchdown. There is a disadvantage of discomfort when disembarking at mostly greater heights.

2.1.2 Jump from hovering helicopter from the height of less than 2 meters above the solid ground. Within HEMS, this is not used due to a serious risk of injury. This procedure is used in military and police missions. Upon landing, it is necessary to perform a para-roll. From the time point of view, it is the quickest way of non-rope insertion on solid ground.

2.1.3 Jump from hovering helicopter from the height of less than 5 meters above the water surface. The minimum required depth of water is 4 meters. Within HEMS, this is a frequently used procedure in water rescue operations, and from the safety point of view, it is a procedure with acceptable risk. From the time point of view, it is the quickest way of non-rope insertion on water surface.

2.1.4 Helicopter jump during near-the-ground flight from the height of less than 2 meters above the solid ground. The speed of helicopter flight against the Earth's surface must not be greater than $20 \mathrm{~km} \cdot \mathrm{h}^{-1}$. The provisions for jump from hovering helicopter are applicable here. The near-the-ground flight applies when inserting a large number of persons, because it is not necessary to wait until the landing spot is freed by the previous jumper.

2.1.5 Helicopter jump during the near-the-ground flight from the height of less than 5 meters above the water surface. The speed of helicopter flight against the water surface must not be greater than $20 \mathrm{~km} \cdot \mathrm{h}^{-1}$. The provisions for jump from hovering helicopter are applicable here. The near-the-ground flight applies when inserting a large number of persons, because it is not necessary to wait until the landing spot is freed by the previous jumper.

2.1.6 Helicopter insertion with the use of parachute technology limited by weather conditions (minimum height of cloud cover above the ground is 200 meters, maximum wind speed is less than $12 \mathrm{~m} . \mathrm{s}^{-1}$ and minimum dimensions of landing area are $20 \times 20$ meters). It is subject to rigorous and lengthy training. From the time and safety point of view, it is a procedure with acceptable risk. Within HEMS in the region of Central Europe, it is not used. It is rather applied in rescue operations with the 
need to fly long distances, where the scene is first reached by rescue aircrafts and in such case, it is the only way of rescue team insertion.

\subsection{Non-rope procedures for extraction of persons by helicopters from places not permitting helicopter touchdown}

2.2.1 Helicopter embarkation when the landing is not completed (the helicopter is hovering and the landing gear or its part is in contact with a natural or artificial object or surface). It is the most frequently used procedure when the standard helicopter touchdown is not possible. From both time and safety point of view, it is almost comparable with the standard helicopter touchdown. There is a disadvantage of discomfort when embarking at mostly greater heights.

\subsection{Rope procedures for helicopter insertion of persons in places not permitting helicopter touchdown}

2.3.1 Insertion with the use of on-board hoist. This is the most frequently used rope procedure. Maximum hovering height of a helicopter is 80 meters. From the time and safety point of view, it is a procedure with acceptable risk for HEMS.

2.3.2 Insertion by rappelling with the use of mountaineering gear. Maximum hovering height of a helicopter is 100 meters. From the time and safety point of view, it is a procedure with acceptable risk for HEMS. It is subject to more demanding training. It is also used in combination with the procedure referred to in the previous point 2.3.1.

2.3.3 Insertion by rappelling with the use of fast rope. It is the quickest rope insertion procedure. Maximum hovering height of a helicopter is 10 meters. Belaying and self-belaying is not possible here. From the safety point of view, it is therefore considered a procedure with unacceptable risk for HEMS.

2.3.4 Insertion by descending a rope ladder. The optimum hovering height of a helicopter is 5 meters above the ground. It is a lengthy procedure without belaying and from the safety point of view, it is a procedure with unacceptable risk for HEMS. Rope ladder is used predominantly for embarking the helicopter but even so, it is used mostly outside the HEMS.

2.3.5 Transport of rescue workers to the accident site with the use of HEC. The HEC system is made up of a double climbing rope that is attached to the helicopter and at its other end, the transported persons are connected. Rope length for HEC is less than 100 meters, in extreme cases up to 200 meters. This is a time-consuming procedure, if the rope is not installed in advance. However, if the rope is installed on a helicopter before being placed on standby before joining the service (which is the standard procedure for SAR helicopters), this time-consuming requirement is eliminated. From the safety point of view, it is a procedure with acceptable risk for HEMS and is often used in a challenging mountain terrain.

\subsection{Rope procedures for helicopter extraction of persons in places not permitting helicopter touchdown}

2.4.1 Extraction with the use of on-board hoist. This is the most frequently used rope procedure. Maximum hovering height of a helicopter is 80 meters. From the time and safety point of view, it is a procedure with acceptable risk for HEMS.

2.4.2 Extraction with the use of HEC. Rope length for HEC is less than 100 meters, in extreme cases up to 200 meters. This is a time-consuming procedure, if the rope is not installed on a helicopter before being placed on standby. From the safety point of view, it is a procedure with acceptable risk for HEMS and is often used in a challenging mountain terrain. 
2.4.3 Extraction with the use of rope ladder. This procedure is to be used only by trained persons. The optimum hovering height of a helicopter is 5 meters above the ground. It is a lengthy procedure without belaying and from the safety point of view, it is a procedure with unacceptable risk for HEMS. Rope ladder is used for helicopter embarkation mostly outside HEMS.

\section{METHODS}

For the purposes of comparing rope procedures have been created three typical model situations for inserting two persons from a hovering helicopter and two typical model situations for extracting four persons and their transportation on board. During creating these model situations, we have taken into consideration the most frequently used rope procedures within HEMS in civil, military and police sectors of the Slovak Republic. Total insertion/extraction time was considered the basic piece of data for the comparison. Time data were obtained from flight tests, actual training, technical documentation data and on the basis of the expert estimate $[3,5]$. Rope procedures were compared for each helicopter separately and among three types of helicopters most used for these purposes in the Slovak Republic: Mi-17 LPZS, Bell-429 and AGUSTA A109K2. Model scenarios were designed to make it possible to compare them. E.g. times of connection / disconnection of persons on board different helicopters with different cabin dimensions were used the same, although there may be slight differences between them (up to 2 seconds). But rather it depends on the training of the staff.

\subsection{Helicopter insertion of two trained persons (e.g. a rescue worker, a doctor, ...) on the ground}

Insertion has been carried out from a hovering helicopter from the height of 40 meters above the ground. Before the measurement commencement, trained persons have been dressed in full body harnesses and prepared for insertion. For this model situation have been used three following insertion procedures.

3.1.1 Insertion with the use of on-board hoist - lowering one person at a time:

- first person attached themselves to the rope of on-board hoist and took the position for lowering

- measurement begins at the time of the first person's lowering start

- measurement ends at the time of the second person's de-attachment from the rope of onboard hoist after lowering.

3.1.2 Insertion with the use of on-board hoist - lowering two persons at the same time (normally, this procedure is not used but is technically possible):

- both persons attached themselves to the rope of on-board hoist and took the position for lowering

- measurement begins at the time of persons' lowering start

- measurement ends at the time of the last person's detachment from the rope of on-board hoist after lowering.

3.1.3 Insertion by rappelling with the use of static rope and eight descender - one person at a time rappelling:

- first person attached themselves to the rope and took the position for rappelling

- measurement begins at the time of the first person's rappelling start

- measurement ends at the time of the second person's de-attachment from the rope after lowering. 


\subsection{Extraction and transport of four persons (a rescuer + three untrained people) on board a helicopter}

The extraction was carried out using a helicopter hovering above the surface at an altitude of 40 meters. Before starting the measurements, the persons have been outfitted with full body harnesses and prepared for extraction. While following the regulation saying that an untrained rescue people may not be extracted or transported without the presence of a rescuer on a rope, the following two extraction procedures were used for this model situation.

\subsubsection{Extraction and transport aboard a helicopter using an on-board hoist:}

- the rescuer attached themselves and the first untrained person to the on-board hoist's rope.

- measurement starts when the first pair begins ascending

- measurement ends when the rescuer is detached from the rope of the on-board hoist aboard the helicopter.

3.2.2 Extraction using the HEC from a location where landing is not possible, followed by flight with persons attached to the HEC rope to a place where landing is possible, landing and loading/embarkation of the persons aboard the helicopter:

- the rescuer attached themselves and three untrained persons to the HEC rope

- measurement starts when the four persons begin ascending, while to the total time, the time of 10 seconds was also included from the extraction command up to the beginning of the extraction / flight (delay - helicopter take off)

- time delay 15 seconds from the point of view of the helicopter landing on a suitable area for boarding

- measurement ends when the rescuer boards the helicopter.

In this case, it is assumed that the HEC rope was installed before the helicopter was placed in standby. We assume that the helicopter flies in the direction of the target destination of the persons' transport (e. g. towards a medical facility), therefore we consider this time as null here as there is no overall delay. However, in order to compare this procedure with procedure 3.2.1, the times resulting from delays in departure and landing were included in the total time.

\section{RESULTS $[3,5]$}

\subsubsection{Insertion of two persons using the on-board hoist - lowering one person at a time}

\begin{tabular}{|l|c|c|c|}
\hline helicopter & Mi-17 LPZS & BELL-429 & AGUSTA A109K2 \\
\hline on-board hoist & HS-29900-59 & $\begin{array}{c}\text { Rescue Hoist model } \\
44316\end{array}$ & HS-29700 \\
\hline lowering/raising speed (m.s ${ }^{-1}$ ) & $1.78 / 1.78$ & $1.32 / 1.27$ & $1.07 / 0.71$ \\
\hline lowering of the first person (sec.) & 22.5 & 30.3 & 37.4 \\
\hline $\begin{array}{l}\text { detachment of the first person } \\
\text { (sec.) }\end{array}$ & 5 & 5 & 5 \\
\hline raising the rope (sec.) & 22.5 & 31.5 & 56 \\
\hline $\begin{array}{l}\text { attachment of the second } \\
\text { person (sec.) }\end{array}$ & 5 & 5 & 5 \\
\hline $\begin{array}{l}\text { lowering of the second person } \\
\text { (sec.) }\end{array}$ & 22.5 & 30.3 & 5 \\
\hline $\begin{array}{l}\text { detachment of the second } \\
\text { person (sec.) }\end{array}$ & 5 & 5 & 145.8 \\
\hline total time (sec.) & 82.5 & 107.1 & 5 \\
\hline
\end{tabular}

Table 1: Results of insertion of two persons using the on-board hoist - lowering one person at a time 


\subsubsection{Insertion of two persons using the on-board hoist - lowering two persons simultaneously}

\begin{tabular}{|l|c|c|c|}
\hline helicopter & MI-17 LPZS & BELL-429 & AGUSTA A109K2 \\
\hline on-board hoist & HS-29900-59 & $\begin{array}{c}\text { Rescue Hoist model } \\
44316\end{array}$ & HS-29700 \\
\hline lowering/raising speed (m.s- ${ }^{1}$ ) & $1.78 / 1.78$ & $1.32 / 1.27$ & $1.07 / 0.71$ \\
\hline lowering of two persons (sec.) & 22.5 & 30.3 & 37.4 \\
\hline $\begin{array}{l}\text { detachment of two persons } \\
\text { (sec.) }\end{array}$ & 10 & 10 & 10 \\
\hline total time (sec.) & 32.5 & 40.3 & 47.4 \\
\hline
\end{tabular}

Table 2: Results of insertion of two persons using the on-board hoist - lowering two persons simultaneously

\subsubsection{Insertion of two persons using a static rope and a figure eight device}

\begin{tabular}{|l|c|c|c|}
\hline helicopter & MI-17 LPZS & BELL-429 & AGUSTA A109K2 \\
\hline rappelling speed $\left({\left.\mathrm{m} . \mathrm{s}^{-1}\right)}^{\text {rappelling of the first person }}\right.$ & 5 & 5 & 8 \\
\hline $\begin{array}{l}\text { (sec.) } \\
\text { detachment of the first person } \\
\text { (sec.) }\end{array}$ & 8 & 5 & 5 \\
\hline $\begin{array}{l}\text { attachment of the second } \\
\text { person (sec.) }\end{array}$ & 5 & 5 & 5 \\
\hline $\begin{array}{l}\text { rappelling of the second person } \\
\text { (sec.) }\end{array}$ & 8 & 8 & 8 \\
\hline $\begin{array}{l}\text { detachment of the second } \\
\text { person (sec.) }\end{array}$ & 5 & 5 & 5 \\
\hline total time (sec.) & 31 & 31 & 31 \\
\hline
\end{tabular}

Table 3: Results of insertion of two persons using a static rope and a figure eight device

\subsubsection{Extraction of four persons and their transport aboard a helicopter using an on-board} hoist

\begin{tabular}{|l|c|c|c|}
\hline helicopter & MI-17 LPZS & BELL-429 & AGUSTA A109K2 \\
\hline on-board hoist & HS-29900-59 & $\begin{array}{c}\text { Rescue Hoist model } \\
44316\end{array}$ & HS-29700 \\
\hline lowering/raising speed (m.s- ${ }^{-}$) & $1.78 / 1.78$ & $1.32 / 1.27$ & $1.07 / 0.71$ \\
\hline Extraction of the first pair (sec.) & 22.5 & 31.5 & 56 \\
\hline $\begin{array}{l}\text { Detachment of the first person } \\
\text { (sec.) }\end{array}$ & 5 & 5 & 5 \\
\hline Lowering of the rescuer (sec.) & 22.5 & 30.3 & 57.4 \\
\hline $\begin{array}{l}\text { Attachment of the second } \\
\text { person (sec.) }\end{array}$ & 5 & 5 & 56 \\
\hline $\begin{array}{l}\text { Extraction of the second pair } \\
\text { (sec.) }\end{array}$ & 22.5 & 51.5 & 5 \\
\hline $\begin{array}{l}\text { Detachment of the second } \\
\text { person (sec.) }\end{array}$ & 5 & 30.3 & 37.4 \\
\hline Lowering of the rescuer (sec.) & 22.5 & 5 & 5 \\
\hline $\begin{array}{l}\text { Attachment of the third person } \\
\text { (sec.) }\end{array}$ & 5 & 31.5 & 56 \\
\hline $\begin{array}{l}\text { Extraction of the third pair } \\
\text { (sec.) }\end{array}$ & 22.5 & & 5 \\
\hline
\end{tabular}




\begin{tabular}{|l|c|c|c|}
\hline $\begin{array}{l}\text { Detachment of the third pair } \\
\text { (sec.) }\end{array}$ & 10 & 10 & 10 \\
\hline total time (sec.) & 142.5 & 185.1 & 272.8 \\
\hline
\end{tabular}

Table 4: Results of extraction of four persons and their transport aboard a helicopter using an on-board hoist

\subsubsection{Extraction of four persons using the HEC and their transport aboard a helicopter}

\begin{tabular}{|l|c|c|c|}
\hline helicopter & MI-17 LPZS & BELL-429 & AGUSTA A109K2 \\
\hline $\begin{array}{l}\text { delay - helicopter take off } \\
\text { (sec.) }\end{array}$ & 10 & 10 & 10 \\
\hline helicopter flight (sec.) & $\begin{array}{l}\text { We assume that the helicopter flies in the direction of the target } \\
\text { destination of the persons' transport (e. g. towards a medical } \\
\text { facility), therefore we consider this time as null here as there is } \\
\text { no overall delay }\end{array}$ & 15 \\
\hline delay - helicopter landing (sec.) & 15 & 20 & 20 \\
\hline $\begin{array}{l}\text { detachment of the foursome } \\
\text { (sec.) }\end{array}$ & 20 & 20 & 20 \\
\hline $\begin{array}{l}\text { loading of the foursome aboard } \\
\text { the helicopter (sec.) }\end{array}$ & 20 & 65 & 65 \\
\hline total time (sec.) & 65 & 15 & 15 \\
\hline
\end{tabular}

Table 5: Results of extraction of four persons using the HEC and their transport aboard a helicopter

\section{DISCUSSION}

\subsection{Insertion of two people from the helicopter (results in 4.1.1, 4.1.2 and 4.1.3)}

5.1.1 The comparison of methods for insertion of two persons using an on-board hoist speaks (for each helicopter), in terms of time, clearly in favor of the procedure when both persons are lowered simultaneously. This method is, however, rarely used in practice. Positioning two persons simultaneously for lowering, while the backpacks of both need to be transported as well, is very complicated due to the limited space aboard and in the door. This means that two persons would need to be lowered without their backpacks, which would be lowered separately afterwards. In terms of overall time it would be the same as lowering one person with a backpack at a time. In practice, therefore, insertion by lowering one person at a time, using the on-board hoist, is utilized more often - method 4.1.1.

5.1.2 The comparison of insertion methods for lowering two persons by using an on-board hoist and by rappelling speaks (for each helicopter), in terms of time, clearly in favor of the insertion by rappelling procedure. While this method requires more demanding training, the time savings compared to the on-board hoist (procedure 4.1.1) are significant. Cutting the time of insertion by 50 to 115 seconds is a huge benefit not only in terms of the duration of the rescue mission, but also in regards to the helicopter often having to remain in hover in very difficult piloting conditions. The preference of rappelling to lowering of two persons by an on-board hoist is therefore advantageous in terms of time. This, however, gets more complicated in the event of a failure of one engine, because the on-board hoist provides the ability to raise the person back aboard or unwind them behind the helicopter for an emergency landing, even during a single-engine flight. If one person is required to insertion, the onboard hoist procedure is comparable in time to rappelling (time is only about 5 to 15 seconds longer).

5.1.3 A comparison of performance of on-board hoists of the helicopters Mi-17 LPZS, BELL-429 and AGUSTA A109K2 while lowering is, in terms of time, clearly in favor of the Mi-17 LPZS with an on-board hoist model HS-29900-59. The lowering and raising speeds of this on-board hoist are approximately 
$27 \%$ higher in comparison with the on-board hoist of the BELL-429 helicopter and approximately 50\% higher in comparison with the on-board hoist of the AGUSTA A109K2 helicopter.

\subsection{Extraction of four persons and their transport aboard a helicopter (results in 4.2 .1 and} 4.2.2)

5.2.1 A comparison of performance of on-board hoists of the helicopters Mi-17 LPZS, BELL-429 and AGUSTA A109K2 in extraction is, in terms of time, clearly in favor of the Mi-17 LPZS with an on-board hoist model HS-29900-59. The extraction of four persons using an on-board hoist is, however, nearly unacceptable in terms of time. The continual hover of a helicopter at an altitude of $\mathbf{4 0}$ meters for a period of 143 to 273 seconds is very difficult in terms of piloting, and, in difficult weather conditions, often impossible to execute. Therefore, it is more convenient to pick up and transport more than two persons using the HEC - procedure 4.2.2.

5.2.2 The extraction of four people using the HEC and their following transport aboard a helicopter in a total time of 65 seconds is a significantly more time-efficient procedure compared to the on-board hoist. The only disadvantage is the fact that it is necessary to carry out a flight to the nearest appropriate landing zone with persons in the HEC, where the persons from the HEC can board the helicopter. This disadvantage of this procedure can become limiting in situations involving extraction from water surfaces in cold or rainy weather. The persons in HEC run the risk of hypothermia and, in longer flights, even freezing. However, if the flight does not take more than one to two minutes, this procedure is acceptable in any conditions. In the case of a flight time longer than 2 minutes, which is required for landing for boarding, the HEC method is mostly unsuitable. In the conditions of the Slovak Republic it is, therefore, more appropriate to use the HEC for extraction of more than two persons [7]. If necessary extraction one or two people, it is better to use the on-board hoist. Based on the abovementioned reasons it is also true that in coastal countries and in rescue operations taking place more than $10 \mathrm{~km}$ from the coast, the on-board hoist is the only viable option of extracting persons from the sea [8].

\section{CONCLUSION}

The decision regarding the method of insertion and extraction of persons during rescue missions is solely in the hands of the helicopter's pilot, who has to evaluate all influencing factors so as to minimize the risk to flight safety. Among the fundamental evaluated factors are wind speed and direction, turbulence, altitude, air temperature, location (water/land), position of the persons (free terrain/up a tree/on a roof/in a rock wall), terrain features (plain/mountainous terrain/mountain-climbing terrain), forestation and its height, the number of persons requiring transport and more [8]. The simplest and most secure method is always preferred. For example, if it is possible to land the helicopter in the vicinity of the accident, this approach is definitely prioritized over any other procedure. Furthermore, in the case of rope methods, circumstances regarding possible engine failure are taken into account, which means that the helicopter needs to remain in hover mode for as short a time as possible. The factor of time is obviously also important in rescue missions - in terms of providing first aid and the transport of injured persons to a medical facility. A comprehensive assessment of all these circumstances and making the right decisions requires years of experience from real-world interventions, as well as challenging and intensive training. Only in this case is it possible to use the HEMS with acceptable risk. 


\section{REFERENCES}

[1] Kalavsky, P. (2009: Alternatívne spôsoby vysadenia osôb a transportu osôb pomocou vrtul'níkov s využitím lanových a nelanových techník a letecká záchrana (Alternative ways of insertion and extraction of people by helicopters using rope and non-rope procedures and search and rescue service). Textbooks. Slovak Aeronautical Institute JSC, Kosice

[2] Kalavsky, P. (2006): Zlaňovacie a podvesové zariadenie pre vrtul'ník Mi-2, Mi-17 a Mi-24 (Rappelling and human external cargo equipment for helicopter Mi-2, Mi-17 and Mi-24). Regulation for Slovak Armed Forces. Slovak Aeronautical Institute JSC, Kosice

[3] Kalavsky, P. (2006): Zápis o výsledkoch pozemných a letových skúšok projektu Zlaňovacie a podvesové zariadenie pre vrtul'ník Mi-2, Mi-17 a Mi-24 (Record of the ground and flight test results of the project Rappelling and human external cargo equipment for helicopter $\mathrm{Mi}-2, \mathrm{Mi}-17$ and $\mathrm{Mi}-$ 24). Slovak Aeronautical Institute JSC, Kosice

[4] Kalavsky, P. (2006): Školenie osôb v oblasti alternatívnych spôsobov vysadenia osôb a transportu osôb pomocou vrtul'níkov s využitím lanových a nelanových techník (Training in the alternative ways of insertion and extraction of people by helicopters using rope and non-rope procedures). Štúdia vypracovaná v rámci projektu Padáková a výsadková technika počas hospodárskej mobilizácie (Study commissioned by the project Parachute and airborne equipment during the economic mobilization). Slovak Aeronautical Institute JSC, Kosice

[5] Flight manuals for Mi-17 LPZS, AGUSTA A109K2 and BELL 429

[6] Kika, T. (2015): Practical aspects of aviation rescue in the mountains. JAMES http://www.james.sk/file/medicina/2015pel14.pdf

[7] Kalavsky, P.; Trautenberger, L. (2006): Upevnenie zlaňovacieho a podvesového zariadenia na vrtul'ník pre potreby evakuácie osôb z miest vylučujúcich pristátie vrtul'níka (Attachment of a rappelling and human external cargo equipment to evacuate people from the sites not suitable for landing of a helicopter). In: Fire protection and rescue services. Zilina, ISBN 80-8070-539-9

[8] Glomseth et al. (2016): Ambulance helicopter contribution to search and rescue in North Norway. In: Scandinavian Journal of Trauma, Resuscitation and Emergency Medicine 24:109. DOI 10.1186/s13049-016-0302-8

\section{COPYRIGHT STATEMENT}

The authors confirm that they, and/or their company or organization, hold copyright on all of the original material included in this paper. The authors also confirm that they have obtained permission, from the copyright holder of any third party material included in this paper, to publish it as part of their paper. The authors confirm that they give permission, or have obtained permission from the copyright holder of this paper, for the publication and distribution of this paper as part of the READ 2018 proceedings.

This is an open access article distributed under the Creative Commons Attribution License which permits unrestricted use, distribution, and reproduction in any medium, provided the original work is properly cited. (CC BY 4.0). 